\title{
Ring sequestrum of the tibia
}

\section{Raju Vaishya, ${ }^{1}$ Abhishek Vaish ${ }^{2}$}

${ }^{1}$ Department of Orthopaedic \& Joint Replacement Surgery, Indraprastha Apollo Hospitals, New Delhi, India

${ }^{2}$ Department of Orthopaedics, Sancheti Hospital, Pune, Maharashtra, India

\section{Correspondence to} Professor Raju Vaishya, raju.vaishya@gmail.com

Accepted 6 April 2014

\section{DESCRIPTION}

A 43-year-old man presented with recurrent pus discharge from his left upper leg for the past 3.5 years. He has had a gunshot injury to the left hip leading to fracture dislocation of the left hip. Initially, he was treated by skeletal traction using Steinmman pin through the upper left tibia. This was followed by pin tract infection, which persisted. The patient took various broad-spectrum antibiotics (eg, amoxiclav, erythromycin, cefuroxime, amikacin, ciprofloxacin, etc), off and on for about 2 years. Now, he had a pus discharging sinus on the anterolateral aspect of the upper leg with surrounding discolouration of the skin (figure 1). Wound swab culture grew Pseudomonas aurues. Radiograph of the upper leg showed a ring sequestrum in the upper tibia, surrounded by dense sclerosis (figures 2 and 3 ). Saucerisation of the cavity was done with complete removal of sequestra and all granulation tissues (figure 4). The wound healed in 10 days time, without any discharge or symptoms.

Metallic pin insertion for providing skeletal traction and external fixation, in major fractures of the lower limb is common. ${ }^{1}$ Minor pin tract infection occurs in $5-10 \%$ of patients, and these usually respond to antibiotic therapy and local wound care. However, in $4 \%$ of these patients, chronic pin tract osteomyelitis may develop, ${ }^{2}$ which is seen on the radiograph as a ring sequestrum. ${ }^{3}$ Staphylococcal osteomyelitis is reported more common in short-term fixator use, while Gram-negative rod infections are common with

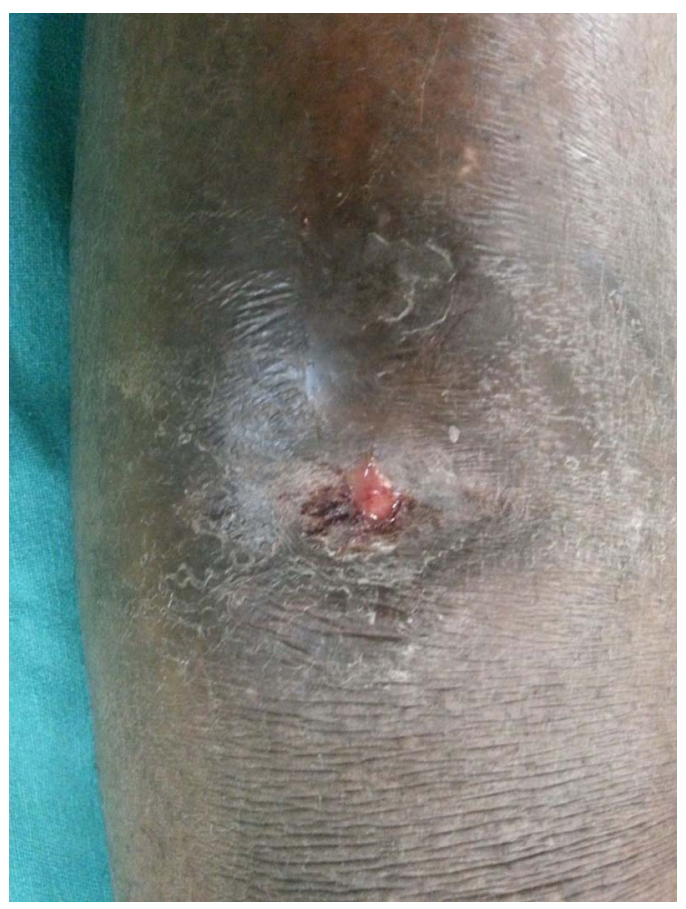

Figure 1 Pus discharging sinus on the anterolateral aspect of the upper leg.

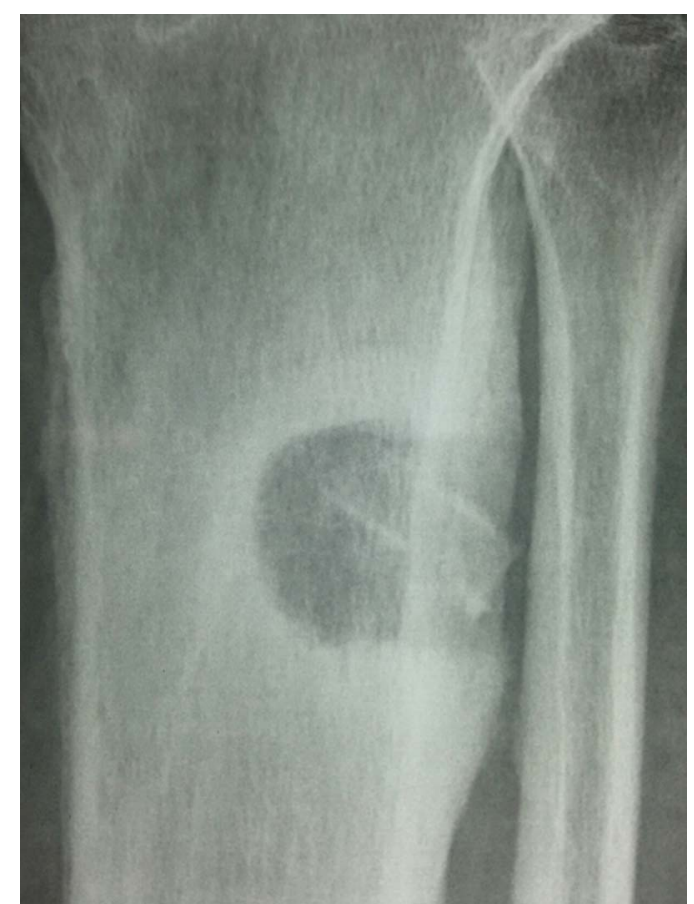

Figure 2 Anteroposterior view of the leg showing chronic osteomyelitis of the upper tibia.

long-term use. ${ }^{4}$ The treatment of chronic pin tract infection includes removal of pins, appropriate antibiotic therapy and saucerisation of the cavity with removal of sequestra. ${ }^{25}$

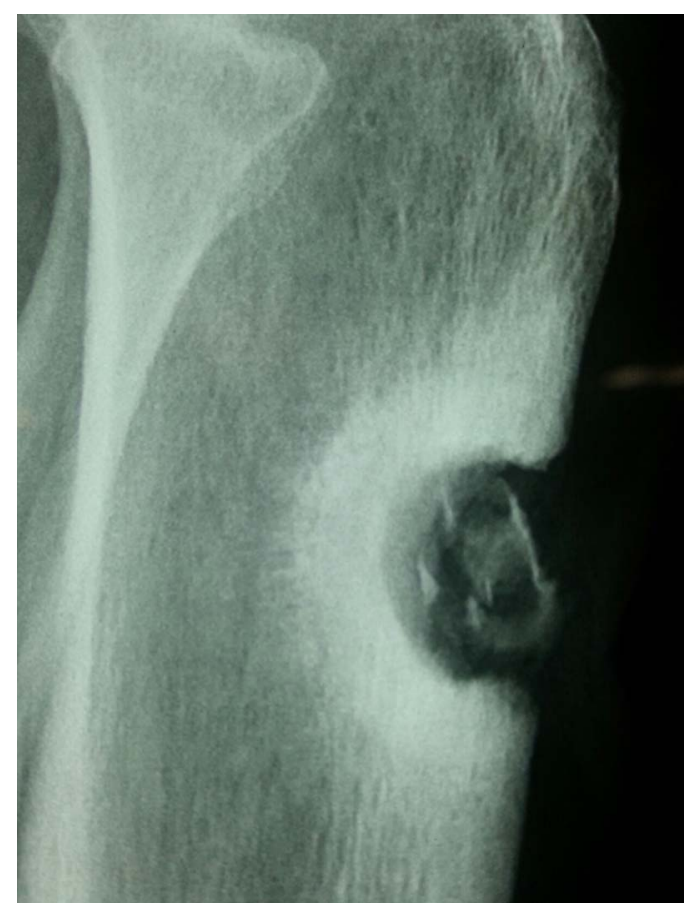

Figure 3 Lateral view of the leg showing ring sequestrum with surrounding dense sclerosis in the upper tibia. 


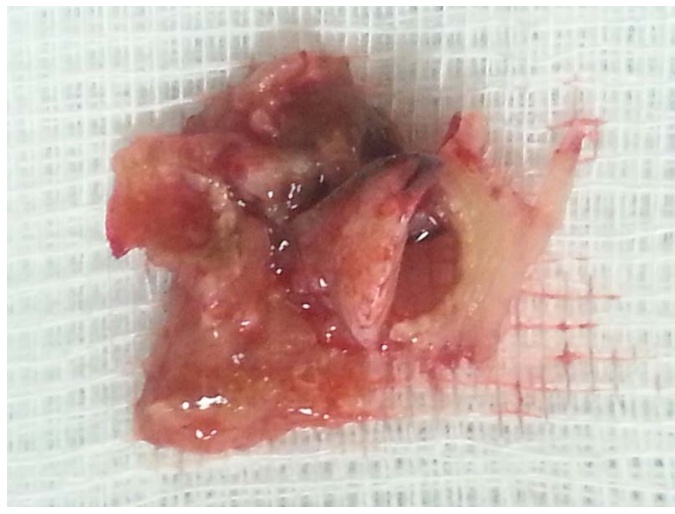

Figure 4 Excised ring sequestrum with granulation tissue.
Provenance and peer review Not commissioned; externally peer reviewed.

\section{REFERENCES}

1 Sisk TD. General principles and techniques of external skeletal fixation. Clinical Orthop Rel Res 1983;180:96-100.

2 Green SA. Complications of external skeletal fixation. Clin Orthop Rel Res 1983;180:109-16.

3 Nguyen VD, London J, Cone RO. Ring sequestrum: radiographic characteristics of skeletal fixation pin-tract osteomyelitis. Radiology 1986;158:129-31.

4 Green SA, Ripley MJ. Chronic osteomyelitis in pin-tracts. J Bone Joint Surg 1984;66:1092-8.

5 Selegson D, Harman K. Negative experiences with pins-in-plaster for femoral fractures. Clin Orthop Rel Res 1979;138:243-145.

\section{Learning points}

- Metallic pins in the bone must be inserted cautiously and kept with due care, as the damage to bone and superadded infection may lead to chronic osteomyelitis.

- Treatment of chronic pin tract infection is usually surgical.

\section{Competing interests None.}

Copyright 2014 BMJ Publishing Group. All rights reserved. For permission to reuse any of this content visit http://group.bmj.com/group/rights-licensing/permissions.

BMJ Case Report Fellows may re-use this article for personal use and teaching without any further permission.

Become a Fellow of BMJ Case Reports today and you can:

- Submit as many cases as you like

- Enjoy fast sympathetic peer review and rapid publication of accepted articles

- Access all the published articles

- Re-use any of the published material for personal use and teaching without further permission

For information on Institutional Fellowships contact consortiasales@bmjgroup.com

Visit casereports.bmj.com for more articles like this and to become a Fellow 